UDC: 37.032:159.943.8

DOI: 10.26697/ijes.2019.2.05

\section{Legal Consciousness of a Young Specialist as a Problem of Becoming a Modern Expert}

Associate Professor Khlon A. M. ${ }^{1}$

${ }^{1}$ Kyiv National Trade and Economic University, Ukraine

\begin{abstract}
Background:

The development of the legal consciousness of a young specialist is a serious problem of becoming a modern specialist, which arise on the difficult stage of development of the Ukraine. There is necessity approach to the problems of studying the psychology of the development of youth legal consciousness globally, and comprehensively consider the elements of scientific and practical knowledge this problem, for creation a unified approach in forming the concept of understanding the psychology of the development of youth legal consciousness. Conscious attitude to laws and legal norms, law-conscious behavior, understanding legal consciousness from psychology, and solving other issues that arise in a young person are important problem issues that can be explained with the use of ideas about motivation and psychological characteristics. The development of legal consciousness is associated with the formation of public consciousness, which is the basis for building a civil society. Features of forming a young specialist, as a person in the process of becoming, need to study all the components of the formation, including the psychological peculiarities of the development of legal consciousness.
\end{abstract}

\section{Methods: \\ The solution of this problem is possible by attracting scientific approaches psychological, social, managerial, psychometric, psychotherapeutic, and others, which will be understood in its interconnection and unity.}

\footnotetext{
Results:

The younger generation is the flagship of change and an understanding of the factors of development of the legal consciousness of the relevant category needs to studying and analyzed in a situation where our country is in the process of democratic transformation. Questions that arise here are multifaceted and complicated.

We can indicate by appraisal the relation to the right in our country in the context of the analysis of world ratings aimed at studying the level of legal environment that Ukraine is not on the highest levels of such ratings. If we take Ukraine's rating according to the Rule of Law Index, which is one of the basic by defining indicators of the country's provision of legal environment in the country, it is based on the universal principles of the supremacy of the law, calculated by the world non- governmental organization
}

The World Justice Project, then Ukraine as of 20172018 was 77th place with a mark of 0.50 and was between the countries of Serbia and Moldova. The indicator was calculated on the basis of 47 variables. Since 2016, Ukraine's position has increased by one position (78th place and 0.49), yet there is a need for development.

Some dynamics of Ukraine's promotion to higher positions, as we see it, there is, but the pace of development has the potential for improvement. This need scientific research aimed at solution the issues of legal consciousness in the psychological context, first of all, in young professionals.

There is a need for effective measures aimed at reduction the number of crimes committed by minors young people that no less important is for the need to study the factors of development of legal consciousness among young professionals. The problem that must to be solved is the high crime level among the younger generation. Thus, according to the data of the State Judicial Administration of Ukraine, during 2016, 6.041 criminal proceedings against 7.438 juveniles were contemplate by judges of the first instance court, in 2017 there were already 6.408 criminal proceedings against 7.976 juveniles. This indicator may be interdependent with the indicator of the level of legal consciousness among juvenile young people.

Understanding of the factors of development of legal consciousness among young professionals cannot be limited only to the disclosure of crime issues among representatives of the younger generation. Most representatives of the youth choose the way of observance of law and order. The pro-social orientation of the motivation determines the understanding of the importance of realizing its functions of the lawconscious citizen, the awareness of the fundamental tasks associated with the need the understanding of the vectors of their own law-conscious behavior.

\section{Conclusions:}

In this context, it is advisable to develop clear and comprehensive regulations about understanding the psychology of the development of legal consciousness, the formation of a law-conscious attitude to common values and ideals, aspirations to become a full member of society, an individual's efforts to increase his own professional social level and a number of other important social, legal and psychological issues.

\section{Information about the author:}

Khlon Alexander Mikhailovich - Doctor of Philosophy in Psychology, Associate Professor of the Department of Psychology, Kyiv National Trade and Economic University, Kyiv, Ukraine.

Research interests: education and training, psychology; https://orcid.org/0000-0001-9733-8531.

\section{Corresponding Author:}

Khlon Alexander Mikhailovich

\section{Corresponding Author's Email:}

AlexKhlon@i.ua 